\title{
陝北榆林靖邊間的風沙問題
}

\author{
羅 來 興
}

（中阈科罧院地理研究所）

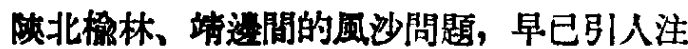
意。流少南渗的䍃害性相當大: 㮬林城址原來靠

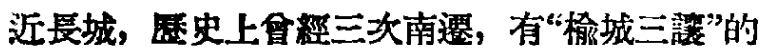
俗語。榆林城西 15 公里的保察堡, 70 年前還是

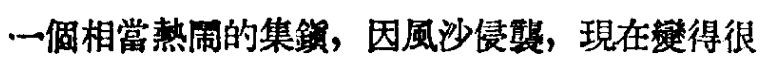
垥落了。榆林战東 20 公里的長樂堡, 在七、八 年內, 城內被沙埋去面積達 $2 / 3$, 西門的沙丘, 高

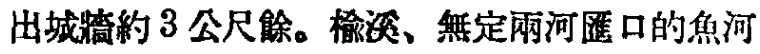
堡, 公元 1852 年(清咸皚二年) 西門城猜因戰爭 被毁，流沙由城的缺口侵政，在最近 100 年間，

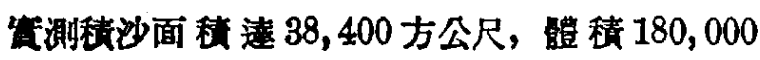

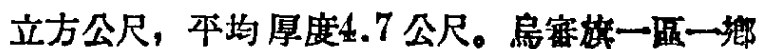
1953 年春季播種面積 $19,405.8$ 市畧, 因風沙侵

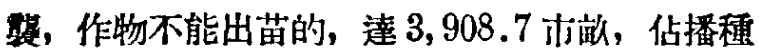
面皘 $20 \%$ 。同年, 聩以縣三區亦因風沙窎害，椇失 禾苗的夏田達 $50 \%$ ，秋 田達 20\%。1952 年春

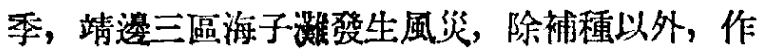
物受害面皘仍達 $30 \%$ ，小橋畔、巴頭灣一帶, 作

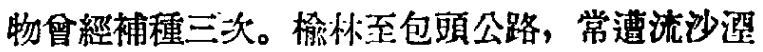
没, 無法通車。總之, 由於流沙侵等, 以致酒沟

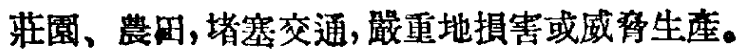

全國解放以後，不少㢈業部門與科學研究機

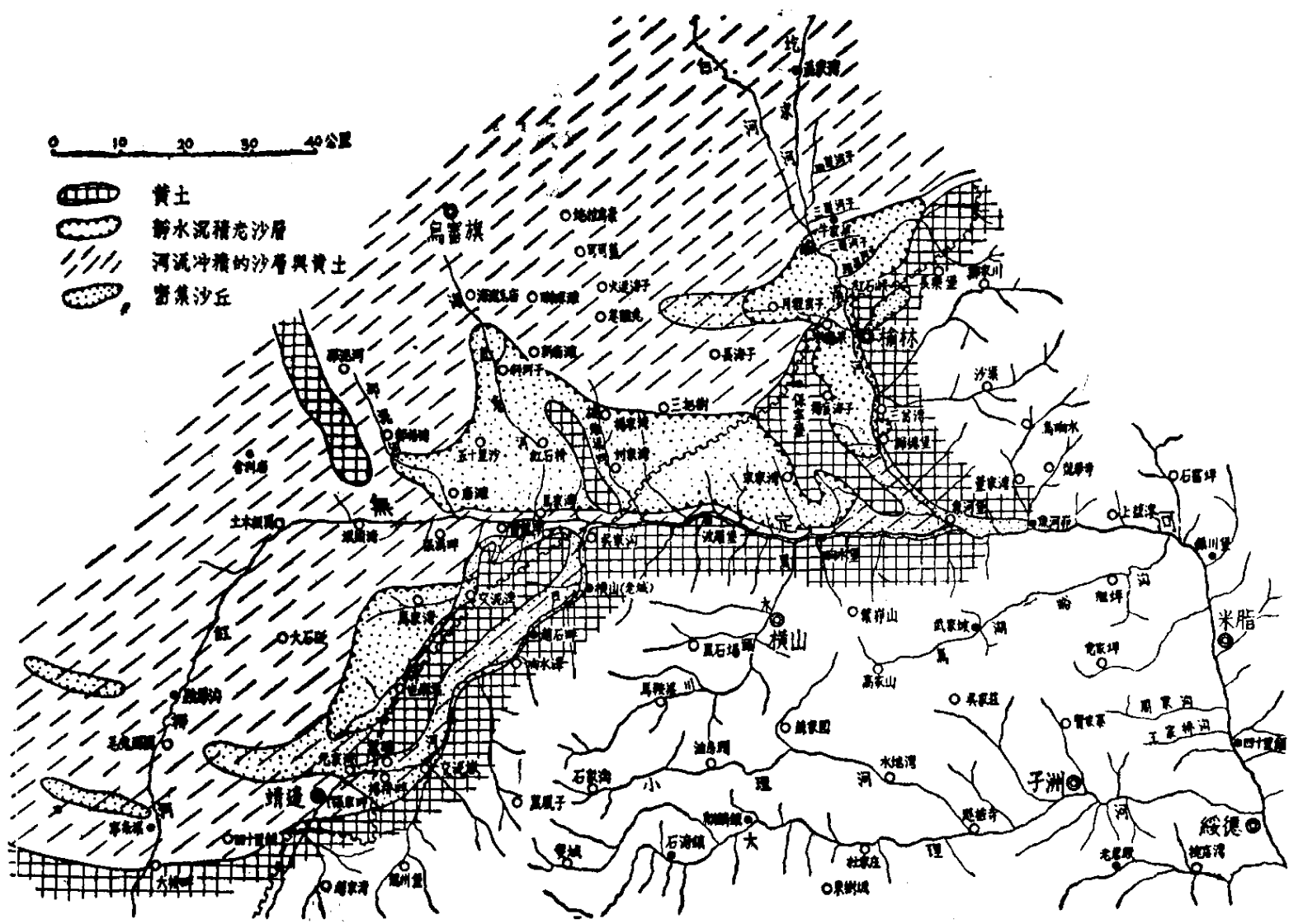

阔 1 地面組成物筫及密集沙丘的分佈 
構派人進行筫地考突。但對於該地區一些有關地 形的問題，例如侵猞主力是“風力”還是“流水”?

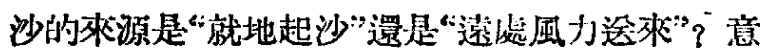
見頗不一致。但㯰些問題，對於决定如何治理與 改造風沙地區的方涂與目標，關係很大。作者於 1953 年夏秋間, 參加黄河水利委員會所組 織 的 “無定河流域水士保持笨脚榢”工作，途經榆林、 烏審嫃、靖邊一帶時, 對於該地區的風沙，會作 過初步觀察。現將這次觀察的結果，作一簡單的 報告，以供進一步討論研究的寥考。

\section{一 地面形態及其組成物面}

榆林、靖邊間的沙帶南緗，界綫明顯(圖 1): 大致自定邊謨的安邊堡，向東經大橋畔、張家畔 (靖透縣治)，沿蘆河經趙石畔、横川舊城至蘆河 口, 再沿無定河經波羅堡、魚河堡, 北上榆溪河

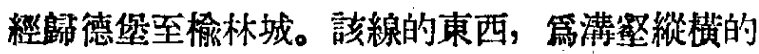
黃土高原。

密集的沙氒，分俳於上述一線的西北, 沙厅 面積最大者有三區（見圖1):一區在㮁添、無定 兩河之間的三牦形地帶，西北越出長城的 10 公 里, 東南尖端他入魚河堡以恵的無定河北岸階地,

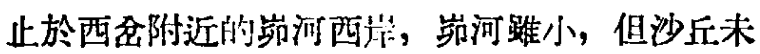
越至東岸一步。另一區在茒泥河與海流兔河下游 的河間地带，當地號称“五十里沙”。還有一區在 黑河的中上游。而泊積較小。

沙丘多成新月型, 狀如籍子 (圖 2)。沙丘; 一般高度約 10 公尺，最高可薘 20 餘公尺，低者

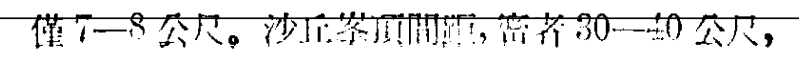

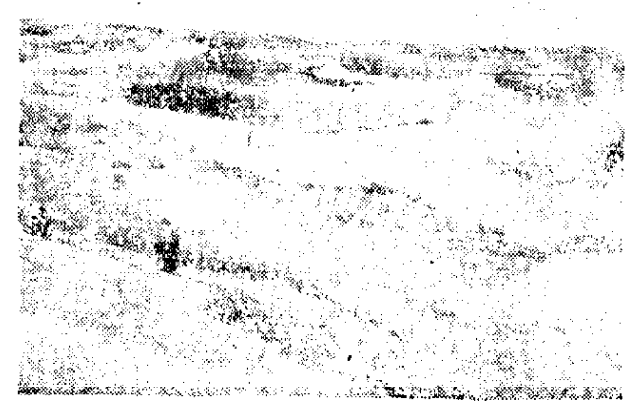

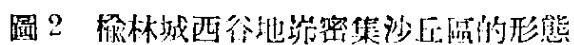

疏者約 100 公尺。沙厅迎風坡，一般朝向西北，

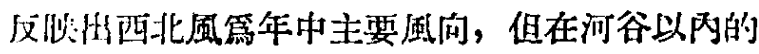

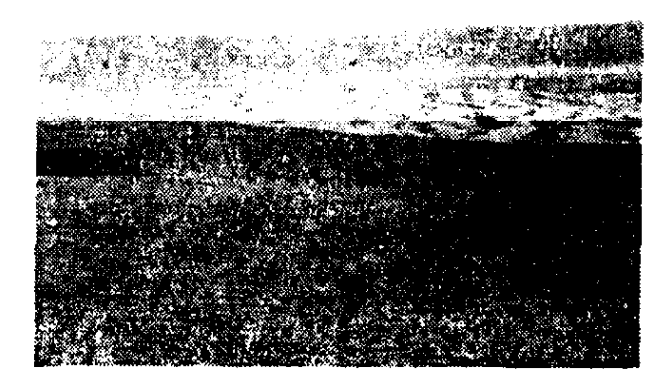

司 3 然定河谷沙 厉的排列

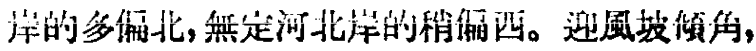
多達 10 度左右，也有接近 20 度的，頂部一段， 由於東南風的倒吹，傾角可達 32 度。而背風坡的 倾角，亦不超出此數，可見 32 度篇該地區散沙的 櫂定解。背風坡脚下，多有空地，作棈圆形（圖 4)，其短的直徑自 10-20 公尺, 深 度由 5-10 公尺。踏地周緣露出的老地面, 有的如平階, 有 的如平桌，風刢擦痕，随處可見。沙丘的管線， 多相連接, 形成與風向垂直的一行一行的沙梁, 沙梁沿線明折如水浪，每一曲弧兩端，伸出䖝低 的沙埂, 沙埂又與沙梁垂直, 因此, 整個沙丘地 面的峯線, 形成方格狀, 方格之內, 即第控地所 在 (圖 5 )。

流經密集沙丘區的河流，如黑河上中游，程 添河以及那泥河、海流兔河、硬地梁河等（無定 河北岸的支流）的下游，谷坡高迋 50-60 公尺， 坡度可達 35 度左右, 但谷底極平, 谷形忽寛忽窄, 筧者達 500-800 公尺，窄者僅 50-100 公尺，状 如胡蘆。現時的水槽, 就在坦平的谷底敦, 左右 曲，居民利用河水灌溉，水稻與旱作应量均甚 高。谷頂地面, 即篇一片黄沙。

由於河谷的割切，可以観祭到: 上迅密集少 丘區下部的地面，除魚河堡、西会間無定河北捍的

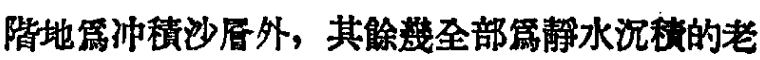
沙居(見圖 1)，水平居理明晰，沙居內夾有兩、 三畨泥炭土，薄者 0.5 公尺，厚者近 2 公尺，泥 炭层上下，有筞植資缶土。遭種剖面的存在，極 篇普漏，反胦出在從前遭些地區是排水不良的沼

\section{3 月號}

科學 通 報

- 41 . 
澤地帶。

在静水沅積沙展的地區, 現時塄有若干路地, 皘水成沼，當地稱篇“海子”。海子的排列，由西 北海向東南，與今日的河流流向一致，特合地面總 便䣄的方向。查勘時發現海子潰决成河的兩個實 例: 一舀踣德堡對岸的新開溝, 從前原是三、四 個电連的海子, 1884 年（清光緒十年）農曆 8 月 間，露雨数日，海子被冲開，據說潰沙堵塞榆淡 河, 河水倒漾 5 公里，隔一年水才暢流。二第無 定河北岸响水堡西 10 公里的方家筝，也在同一時 期，一連串的海子被冲開，指說溃沙亦把無定河 堵塞，三年後河水才啺流。現時兩满口還有殘餘 積沙，形成高約 5 公尺餘被割的冲積征。由於道 兩個筧例，可以推想到古代沙居沉積以後，會有

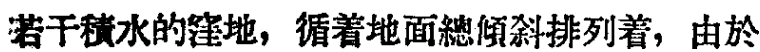
展透水，相鄰的海子，地下發生酯流，倘遇反 常的暴雨, 就可能將一連串的皘水等地冲開成河， 上迅那些河流都有湖薶形的河谷，可能即脫胎於 此。

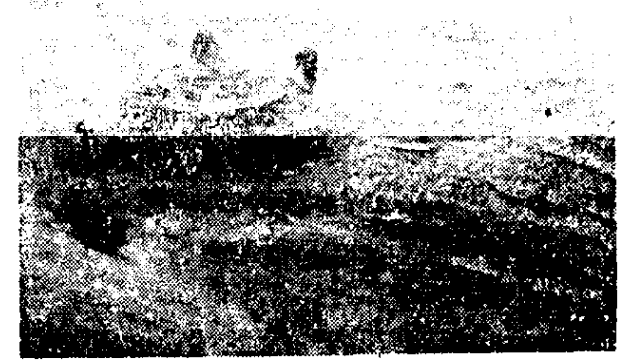

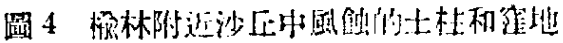

密集沙氒區以外的地面，第坦平的草原，村 落較多，耕地成片，牛羊成輁，景色就不是像䗱 集沙斥地帶的那樣洗分了(圖 6)。選種草原當地 居民稱篇 “灌地”或“乾海子”。自榻林出 長城 不遠, 就能看見。幕原的分体, 忿向西北忿多, 面皘亦恿大, 在烏審旗政府所在地的大不䩞, 以

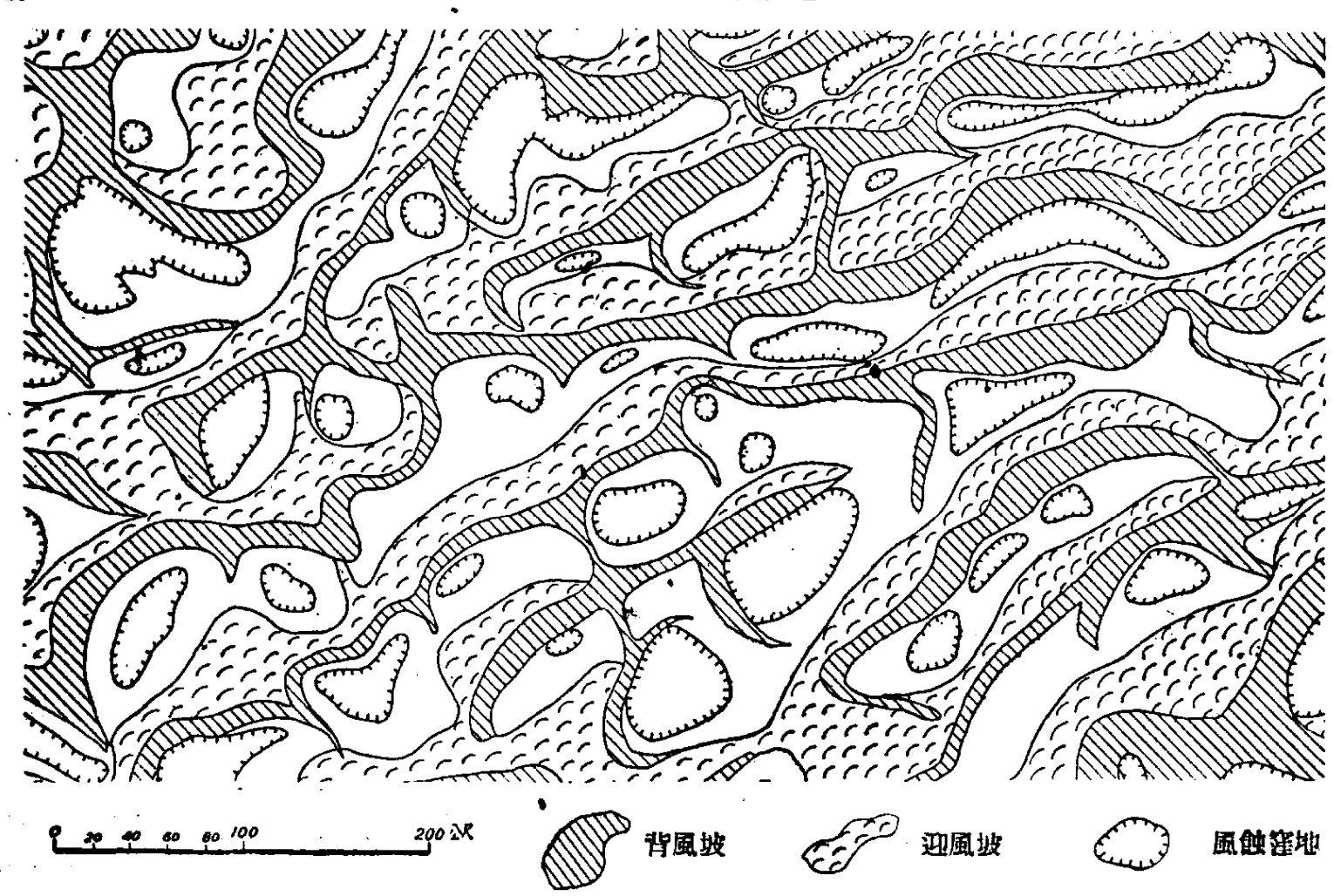

（蹦 5 湓林附近的沙丘地形

及由大不䩞西南至城川途中, 草原面積, 一等無

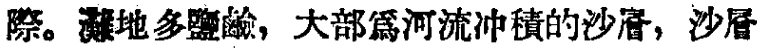
中夾有秥壤土.小部第冲皘黄土展, 但它的表面仍 有沙展分倣。稚地潛水面甚高, 離地面由數公寸

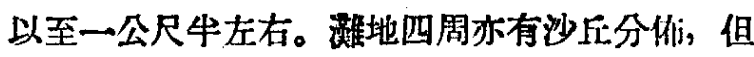
沙丘简僅 4-5 公尺, 間距疏涬跉百公尺, 而目在

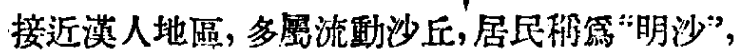
在蒙人居任地方，沙丘窟沙落、沙柳等所固定。 


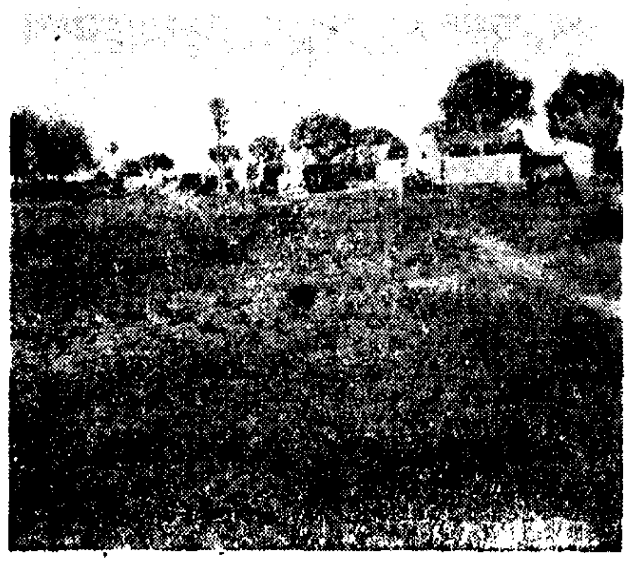

圖 6 草原上的忽䌖兔村莊

破源於草原的河流，如那泥河、海流兔河、 硬地梁河及榆添河等, 上游地勢平坦遼濶, 河谷

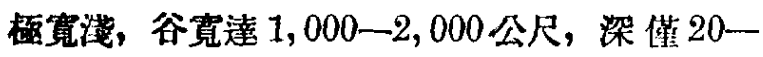
30 公尺, 居民亦稱“灘地”。但幹谷與支谷, 體系 完整, 分割地面, 形成平岡, 無疑篇流水侵刢的 㢈物。

上迌皘沙帶南緣的冀土高原，在川坡脚下， 往往有成叢的殘丘, 像填堆一樣, 或成柱狀, 或 成錐體。丘側刻劃詐多線狼, 周圍就有積沙（圖 7 ), 這 固然是風玲的結果, 但因景色觸 目, 以 致一般人很容易誇大風力的作用，凘則整個山坡 與河谷, 均篇流水侵蚀的産物，風刢不過是表面 的彫而已。

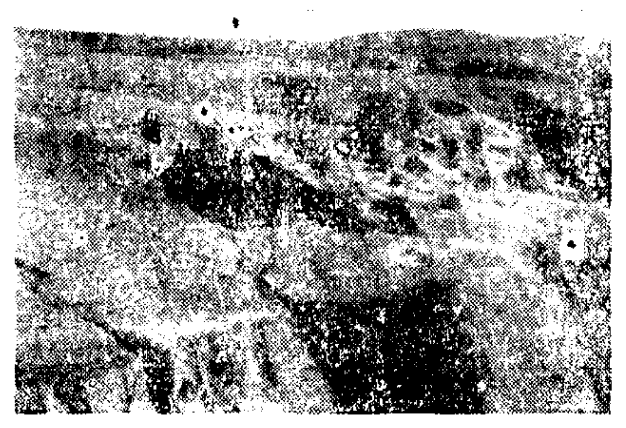

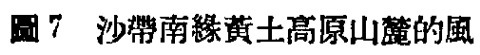
触牫丘，踈如一裳境堆

黄士高原邀緗的河谷內，谷坡亦有積沙，例 如臀河與紅柳河.上游, 無定河南岸與榆滛河東岸 的支谷中，都叮見到。皘沙分㑈最遠處，向東見 於無定河谷鎮川㮩附近，甚至綏德北面的四十里
舖，谷底亦有散沙。但邆些積沙地區，分份零星，

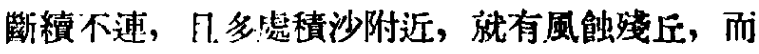

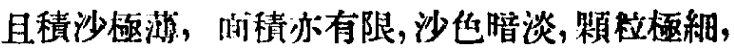
與黄士中的沙粒，很難識別，居民稱篇“犆沙”， 以區別於榆林附近的“明沙”。

\section{二 風力與沙丘發育}

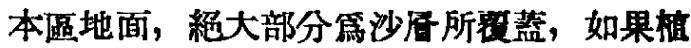
被破壞, 强烈的風力, 就可掀起沙䧶, 形成沙丘。 沙丘的發育, 與風向、風力有密切關係。

區內對於風向、風力有較詳細記载的，僅榆 林一站，其他如趙石䁇、張家甽等地，紀錄短而 不全, 但榆林位置偏北, 地當谷口, 風力較强, 似可代表長城一帶的情况。 -

該站有完整紀錄共 7 年 $(1915$-1953 年, 其 中缺 2 年),年中以西北風篇声, 東南風次之, 南風 亦多, 北風較少。西北風自 9 月可簬剑艺, 10 月篇

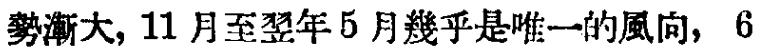
月興 7 月有時仍有西北風出現, 祇有 8 月全没 有西北風。東南風與南風, 主要㻐生在 6-9 月, 2-5 月也偶有墢生。

這種年中風向的分配, 與本區地理位置有關, 因篇本區西北距離戈壁沙漠僅約 500-600 公里,

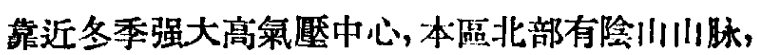
山勢雄偉, 但在西北的狼江與賀闌川之間, 有 150 公里宽的缺口，因而西北氣流，從此可以直入。 反之, 本區東南距崔海洋, 却有 1,000 多公里, 同 時, 東有太行川與吕梁山, 南有中佟川與䅈湍, 諸山脉拔海均在 $2,000-3,000$ 公尺, 東南來的氣 流, 一挫再挫, 踓能越川過颃, 鋒勢究已削弱。

同樣情况，上述地理位置亦影響風力的大小， 本區最大的風力，任何月份均以陌北風第声，北 風次之，東南風則佔絕對少數。陌北風與北風最 大風力篇 5,6 級, 7,8 級風已不常見, 野外可能迋 至 9 級。東南風最大風力, 不過 5,6 䄲而已。

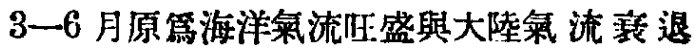
時期, 然而, 本區最大的西北風與北風, 絕多出

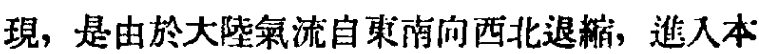

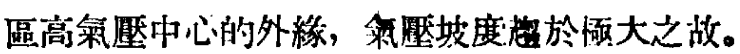
9、10网月第大陸氣流阺盛與游洋策流退維階段, 但由於前者勢力强大, 疑時就能譃展亚筲管中国

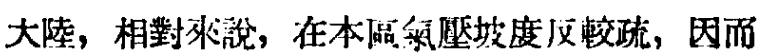


$9 、 10$ 兩月的西北風，较少。

但必須特别指的：年中最大風力的出現，次 数不多, 即在 3-6 月間, 亦非西北風日日吹警不 停, 更非年年均有 $8 、 9$ 敉風。據追悉旗旗長談: 近絊年来，以 1947 年 3 月間一次風最大，在杭錦

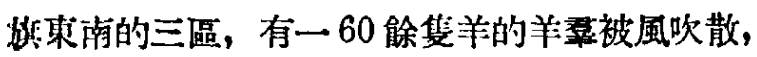
剩下只有 13 隻, 樹木亦被找起, 人在馬上不能 喘氧, 按這種風情, 風力仍難超出 9 級。

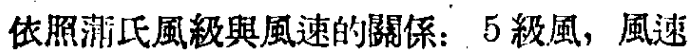
第每秒銅 9.8公介； 6 級風，12.4 公尺； 7 級風， 15.2 公尺，8級風，18.2 公尺。叉掞一般規律， 沙稙俓在 0.65 整米以下者, 每秒鐘 8 公尺的 風速, 就能帶動。根據無定河流域水士保持柾潮 榢土壤組在榆林附近沙斤的沙粒機㑘分析結果, 沙柆直徑很少超出 0.65 撉米, 撸言之, 本區比 校多見的5、6 級大風，是能波動沙粒的。

根㨜上面風力與地面構成物質的分析, 那末, 散沙暴露的地面, 受風力的掃蕩, 沙粘能被帶動, 形成沙丘，是絕對可能的。不過，造亦僅是說風 能赭動沙粒，並不是說沙能篇風吹在空中高飛。

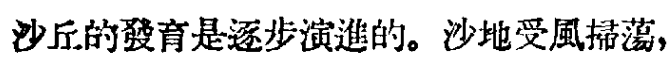
細小的沙麾, 固然可在空中掦，但大部的沙柆， 多沿地面或一定高度前進, 風速一降, 即成“沙 陫”, 不一定要受障礙物才積沙。然而, 事笮上, 任何地面絕非光平如鏡, 一草一石均可成第障碍, 障碍物高者, 沙落於其前, 低者沙落於其後, 但 䛧來的沙，多在障碍物前面向沙源方向堆皘, 逐 潮伸長, 形成與風向一致的長條沙丘, 外貌似覆 招。王舟狀沙丘的迎風面，中線較高，向兩侧科 㑔, 因而，縋來的風，亦必向兩侧散開，一方面， 將兩侧本身的沙，向前帶動，另一方面，被風丧 來的沙，亦陸䫝停皘，兩翼渐次向外擴大，形成 興風向垂值的峯浪。峯浪是中央高雨翼低，沙丘 的迎風面亦成凸弧坡面, 賞風掠過時, 繼續向网腙 散開，將沙向兩翼推進，峯浪逐成凹弧狀。网資 的背風坡，傾角逐漸增大，等到超過珰定角 32 度

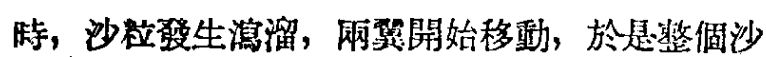

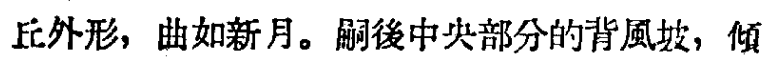
角亦海稳定角時，沙粒亦同樣發生湍溜，至 此階段, 整個沙丘才向前移動。

由於沙丘网省向外搌張，鄰近沙丘彼此連接， 形成一行作弧狀曲折的沙梁, 每一助弧, 鲳示着
昔日沙压的個體; 同時, 又因沙丘两翏向前推進 較速, 䞨上前列沙梁, 就形成與沙梁琴直的沙垻,

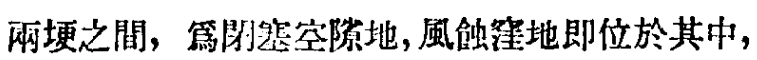
整個地面的沙泿峯線, 組成方格型。上速本區密 集沙丘地楽, 即已發展到連樣階段。

\section{三 沙丘運行的方式與速唺}

上述沙丘的發有，已可想見沙近運行的主要

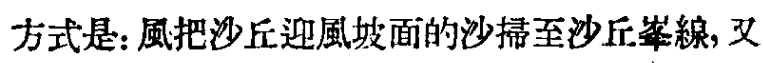
順着背風坡面滑溜下來。大風時, 在野外覞察: 由 沙丘迎風坡面上來的沙, 剛出丘項, 势如昌煙, 但因風力攄散，㩲帶力弱，大部沙粒落在背風坡 而的上部, 繼秸堆積到超過䊝定角時, 即紛粉滑 瀉, 坡度又被制減到杼定角以下, 滑滨作用即行停

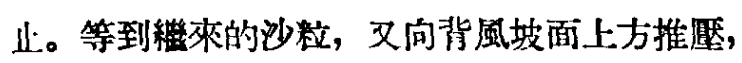
滑滨又重新開始。因此, 我們將沙丘解剖, 自迎 風坡至背風坡的切面，交斜沙居的展理，一律向 東南方向作 32 度的傾科，其理由即在此。又可解 析: 沙丘的含水線, 背風坡面脚下最淺, 是由於 水份沿倾斜沙屡的湥透, 而迎風坡面中部亦淺於 背風坡面中部, 因前者篦濕沙暴露, 後者第乾沙 堆積。

沙丘的高低铇迎風坡面倾角的大小，對於沙 泣運行速度, 有密切關係: 沙丘低而迎風坡粰者, 風力緊貼坡面，沙粒容易推走，沙丘㟯線向前推 憵亦快; 反之, 沙丘高而迎風坡陡者, 風力受阻, 就沿坡昇騰, 與坡面産生空搼, 㩲沙力減弱, 沙 丘峯線向前推原亦較慢。因此, 各個少丘的移怔, 就有快慢不同，當地居民亦有“大嵐 走 得慢，小 岗走得快”的說法。

另一種沙粒運行方式，也是在野外覩 察所 得: 在高密沙丘地帶, 泄風坡面較輕細的沙柆,

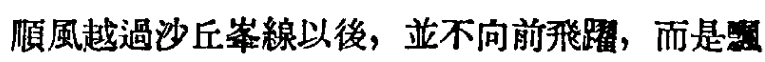
浮於背風面的半坡上, 由於風向與峯線不是真正

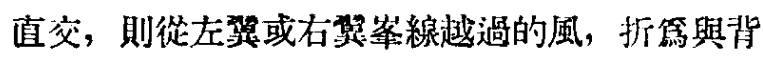

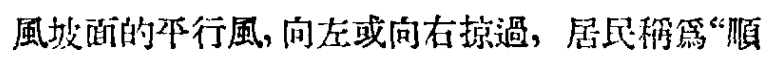

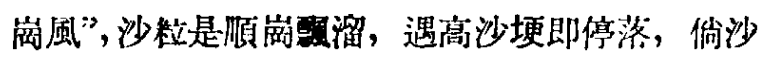
埂過低，仍可向前覆溜。至於由丘顶越過的風， 作拖物線下降, 受前列沙邱迎風坡面之阻, 折成 回旋風, 將背風坡面脚下的細沙掩起, 推充牛坟 上，亦由順溯風向左或向右帶走，風刢落地即篇 順崗風與旋風結合的產物。 
在低疏的近丘地帶, 沙丘前面常有宾䐵本地, 細沙越過峯線以後, 由兩您飛出的沙粒, 成一定 角度相漼, 落成圆形的沙䇛。沙堆離原夾沙丘背 風坡的遠近，視風力的大小及沙丘兩翼的窄宽而 定。由中央吹出沙粒，直问前奔，到處散落， 不過沙量有限, 距離亦不遠。但這一種沙粒運 行方式，也是影響低疏沙丘移動較快的原因之 $\rightarrow$

本區年中以西北風第主, 沙丘多向東南移動, 但夏季的東南風，有時亦相當强烈，上文已有提 及。東南風是由沙丘的背風坡面上吹, 將丘頂的

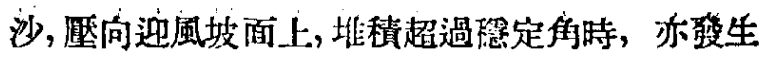

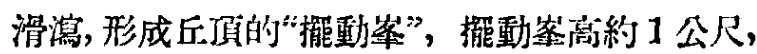
寛涬 1.5 公尺。擺動峑的背風坡 (即沙丘迎風坡 的顶部)，最大倾角亦不超過 32 度。因篇㨢動崒 受風向的轉變而㨢動, 所以沙丘的水分, 以㨢動 峯的背風坡篇最乾, 但整個沙丘向東南移動的速 度, 亦因此而減緩。

關於沙蚱移動的速率，自㮁林至烏審旗途中， 經十六台、長海子、一點沙、忽倠鬼等地, 當地 居民唒能指出確富年代以前的沙压位置, 茲將獲 得的實例，列裴於下:

\begin{tabular}{|c|c|c|c|c|c|}
\hline 地 & 岳形 & “地面 理 境 & 移動距㒕(公尺) & 年 & 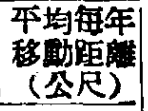 \\
\hline 十六台張家伙場 & 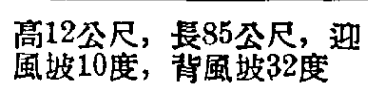 & 灘地高密沙正區 & 背風坡脚移野82公尺 & 32 & 2.56 \\
\hline 長海子陳家房子 & 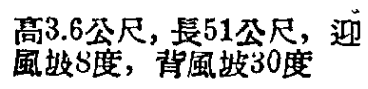 & 灘牠低疏沙卡孟 & 背風坡脚移動59弪尺 & 15 & 3.94 \\
\hline 莀海子、馬家茧紀家 & 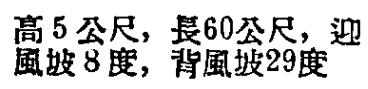 & 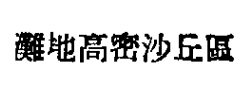 & 互诲等楾移動45公尺 & 16 & 2.81 \\
\hline 長海子騳家层 & 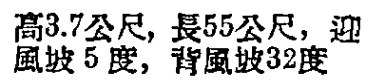 & 潅地低䟽沙丘區 & 丘頂学缐移動70公尺 & 20 & 3.50 \\
\hline 一點沙蚁家伙埸 & $\begin{array}{l}\text { 高 } 5 \text { 爷尺, 長60蛋尺, 迎 } \\
\text { 風坡 } 5 \text { 度, 背坡 } 32 \text { 度 }\end{array}$ & 灘地高密沙压理 & 移動50公尺 & 21 & 2.40 \\
\hline 忽奪鬼白家伙場 & 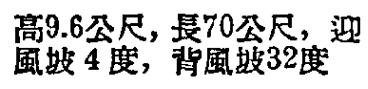 & 醀地低䟽沙丘區 & 互頂崒楾移動 132 公尺 & 41 & 3.22 \\
\hline 忽雉宦白家伙場 & 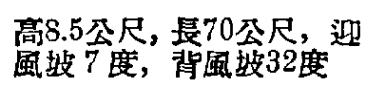 & 䨀地低䟽沙互熰 & 丘項等線移動 111 公尺 & 32 & 3.47 \\
\hline 忽雞鬼白家伙場 & $\begin{array}{l}\text { 高 } 5 \text { 父尺, 長50永尺, 迎 } \\
\text { 風坡 } 6 \text { 度, 度 }\end{array}$ & 灘地低疏沙丘珇 & 互项峯楾移動 84 公尺 & 15 & 5.60 \\
\hline
\end{tabular}

上.表所列移動的沙差, 其前方均篇空曂的灘 地, 员正密集沙丘地區內部, 份未獲得實例, 但 推想其移動速度，必較表中數字篇慢。從表中許 多實例，關於沙丘移動的速來，可歸約出以下規 律:

（1）沙斥移動速秉，本均每年約在 2.4-5.6 公尺之間，一般在 3 公尺左右，並不算快。

（2）如果沙斥間距相同，則低沙丘比高沙丘 移動得快。

（3）如果沙丘高度相同，則閒距密的沙丘比 間距疏的沙丘走得慢。

\section{四 幾點認識與建竬}

棕合以上所述, 對於本區風沙問題, 可作以 下的初步認識:

（1）本區地面，有些地區確是一片黃沙，沙 丘起伏, 猶如敏浪一般, 人煙稀少, 景色荒涼;
但亦有不少地區第本坦逶闊的草原, 村落较多, 耕地成片，牛羊成坡。就侵刢主力來說, 有風蝕 作用, 也有水蝕作用。而且, 以面積而論，水蝳 作用的範裀, 較居上風, 最低限度, 河水仍是外 流的，並非真正的內陸流域。

（2）草原地帶確也有沙丘分佈，但遠較稀䟽， 所佔面積有限。同時草原地面，大部仍篇冲皘沙 首, 接近耕地邊緣, 就起“明沙”。㯰是由於過去 無計劃的過度開䛻，破壞草原所致。

（3）染集沙丘地帶與地面靜水沉積老沙展, 分佈如此巧合, 就不能說兩者毫無關係, 而且老 地面大都是風玲的痕迹, 那林“就地起沙”第沙的 主要來源, 不篇無理。所謂就地起沙, 並不等於 說沙丘不移動。

（1）本區年中主要的西北風，來自戈壁沙漠， 瑟無置疑，因其篇寒季高氣涯中心，整個中國大 陸均受其影響。同時, 風由賀闌川興狼川間的知 
口留進，亦無序議，其理由已如前面所說的。然 栭, 風可從戈壁沙漠吹桃, 但沙是否亦從戈壁沙

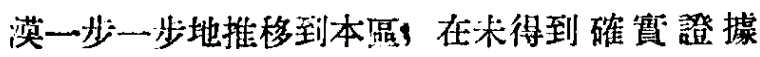
恃, 林敢有所斷言。

（5）於此，還須特别指出：本區風力可以帶 動沙柆, 沙粒的移動及因移動而湮没一些農时,

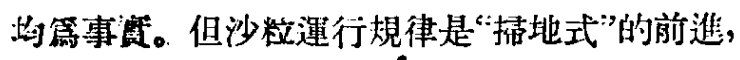
除沙蘑以外, 决不可能由高空越過, 因此, 沙粒 不能由空中波河, 這就是本區皘沙大致以河爫界 的原因。散沙的波河方式，是沙不斷由一岸溜入 河休, 藉水力的搬運, 堆皘於另一岸的灘地上,

\section{第風帶動再前進。}

（6）上交所进的静水沉皘老沙展分們地區, 往古（地質年代）是排水不良的沼澤地帶, 沼澤 地演化篇草原, 本第自然的勢, 而草原經人篇 的破壞, 形成沙斥, 世界上資例也不少, 但不能 喗恣沙丘的存在, 就肯定篇“沙漠”。同時, 本區 氣候, 亦非真正乾旱的沙漠氣候。

（7）在國家經湾集件許可下，營造大規模的 防護林是必要的。西北㖘林部在陝北設計的林帶 位圆, 大致與上述沙帶的南線相符合, 基幹林帶 翼度篇 1,500 公尺, 行距 2 公尺, 株距 1 公尺, 三角栽樹，有些地區已開始營造了。林帶完成以 後, 當然會起防風作用的。不過, 單靠這條林帶, 漫是不能解决問題的。因篇, 沙的來源, 既然以 就地起沙篇主, 那㓅上:迌老沙居分佈地區, 即現時

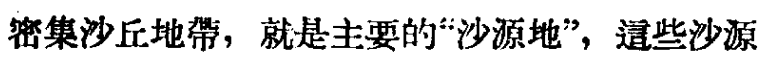
地都位於所設計林帶的西北, 假使不配合進行“固 定沙丘”工作，那枺，散沙還是繼緽不斷地向 林 㛃前方逼過來。不但如此，密集沙丘區以外的草 原, 大部也還是河流䏚请的沙冒, “由於過去無計

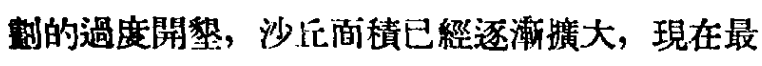
好辦法是停止農耕, 合理墢展牧音。這辦法如果 一時難以筫行, 也應規定祀允許在護田林網保護 下, 才可耕黎, 不然的話, 售沙丘米固定, 新沙 F千文起來。這就是說, 營造林帶必須要與固定沙 丘、護田林網等造林工作相結合, 林帶甫能起作
用，无其要重親固定沙源地沙厅的工作。

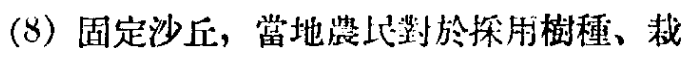
培季節與方法, 都有很多很好的經驗, 值得詳細 調查研究，作出總結。這裏僅藇幾倨例來說: 梢

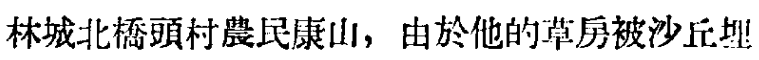
没過, 才開始浩株, 後來沙丘終於被固定了。他 皘累了 10 多年與渢沙阙争的經驗, 認篇造林時 期以農曆寒食 (春季) 與立冬前後最適宜; 沙梁 上可種沙楖、沙蓉, 但因沙梁的乾沙很厚, 截倠時

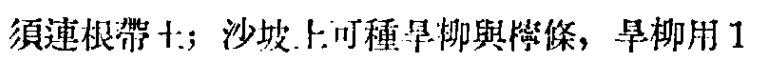

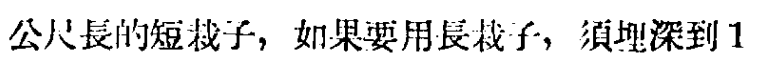

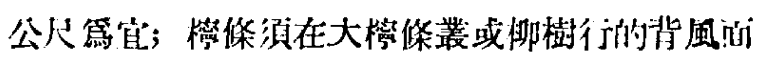

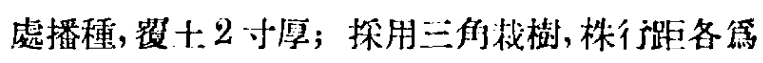
1.5 公尺, 林帶要與主要風向垂直。榆林城酒北

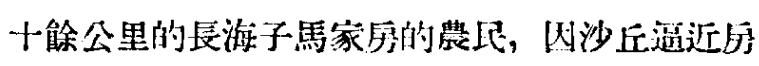
屋, 他就從沙后迎風坡脚, 每年向上裁種线行沙

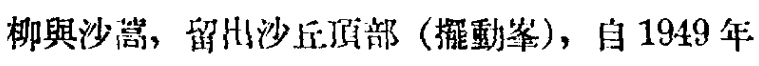
開始截種, 現在沙丘潰部移本了, 但沙丘基部不

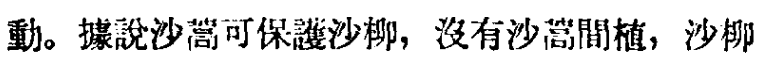
根部容易被風吹簬。横川縣波羅堡的農瓦, 在沙

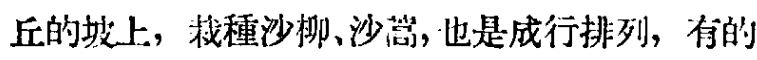

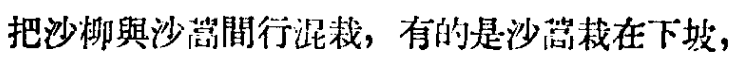

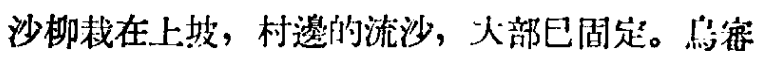

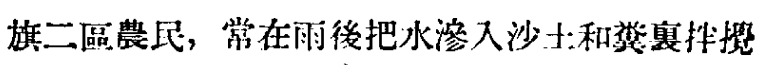

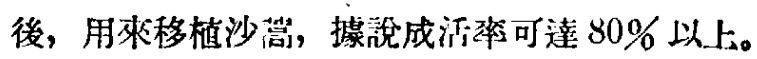

(9) 前面說過, 就地起沙胥沙的主要來源, 縱使沙能從遠處由風力䢒來，但其量必㥛有限。 不過, 烈風肯定是從陌北來的, 无共賀闌川與狼 山間的缺口, 風力必較猛烈。防沙必須防風, 那 末對於密夏的磪口一帶, 是否適宜營造國家防風 林帶, 就有進行查㤼的必要。

（10）洲克昭盟境內的草原, 牧業固然比較 墢澾, 但農業在生產上還是佔着相常大的此禹, 如何進行農、牧兩業的配合, 並在有林網佟件下, 保讙牧音與费耕, 求得土地合理利用, 才是根本 防止風沙辦法, 那就是說, 改造全地區的經澋, 是徹底消隇沙荒的途徑。 